\title{
Drivers of populism - A four-country comparison of party communication in the run-up to the 2014 European Parliament elections
}

\author{
Franzisca Schmidt \\ Universität Bern \\ Fabrikstrasse 8 \\ 3012 Bern, Switzerland \\ franzisca.schmidt@ikmb.unibe.ch
}

\begin{abstract}
The aim of this paper is to analyse what different types of populist communication styles emerged during the 2014 EP election campaign and under which conditions political parties selected specific populist communication styles. To do this, a comparative quantitative content analysis of press releases in the run-up of the latest EP elections has been conducted for parties in France, Germany, Austria and Greece. The paper presents a definition of populism based on the contemporary academic discourse, which focuses on the transnational nature of the European political field. It is shown that populist party communication is more pronounced on the fringes of the political spectrum and in countries struggling with severe macroeconomic difficulties. Contrary to intuitive expectations, the perceived populist rhetoric of exclusivity in the context of the European sovereign debt crisis, which is identified as a central feature of right-wing populism, barely takes place within populist party communication.
\end{abstract}

Keywords: populism, political parties, European elections, comparative analysis, content analysis

\section{Funding}

This work was supported by the Swiss National Science Foundation (SNSF) under Grant 100017E144592/1 and the German Research Foundation (DFG) under Grant MA-2244/5-1.

Version of the article as published in Political Studies 2017, 66(2), pp. 459-479 


\section{Drivers of populism - A four-country comparison of party communication in the run-up to the 2014 European Parliament elections}

\section{Introduction}

Over the last decade, European democracies have faced the challenges of parties and movements that are commonly referred to as being 'populist.' In several EU-member states, the European financial and sovereign debt crisis created fertile soil for parties that use populist rhetoric. José Manuel Barroso, former president of the European Commission, emphasised his increased unease concerning these developments when he spoke at the annual Brussels Think Tank Forum on April 22, 2013: 'I am deeply concerned about the divisions that we see emerging: political extremes and populism tearing apart the political support and the social fabric that we need to deal with the crisis [...]' (Barroso, 2013). Indeed, European elites seem to be increasingly worried by these recent developments, which are perceived as an impending stress test for the Union and the project of European integration as a whole (Hartleb, 2013). As populist communication growingly permeates European politics, it becomes crucial to encompass this phenomenon and shed light on the nature of populist party communication itself. What different forms of populist communication styles emerge in the context of a transnational European political arena? To what extent is this populist rhetoric employed by political parties? And what factors or conditions are constitutive for a party's selection of a specific type of populism? To this effect, the aim of this study is to identify and to explain the usage of different populist communication styles by political parties during the 2014 EP election campaign.

However, systematic comparative analyses of populist communication are scarce (Rooduijn and Pauwels, 2011), as most of the existing empirical investigations of populism are single case studies (e.g. Albertazzi and McDonnell, 2008). This is a consequence of the lack of conceptual clarity that goes along with populism (Barr, 2009; Canovan, 1999; Taggart, 2000) due to its contextual sensitivity. Thus, this paper empirically contributes to the field of populist communication research by employing a comparative research design in order to assess the determinants for the selection of populist communication styles. The theoretical considerations are empirically tested for 28 political parties in Austria, Germany, France and Greece in the run-up of the 2014 EP elections. At that time, all countries involved in the study found themselves in a post-crisis environment still coming to terms with the European debt crisis. However, the crisis' economic, political and social implications have been significantly more incisive for the latter two countries than for Austria and Germany. On this note, the study not only allows for a consideration of decisive party specific factors but also tentatively addresses potential effects of a crisis-hit environment on the selection of populist communication styles.

To measure populism within party communication, I fall back on the conception of Jagers and Walgrave (2007), who perceive populism as a political communication style composed of three rhetorical elements: an appeal to the people in combination with criticism on the establishment and/or the exclusion of others. However, because this study is interested in populist party communication related to the European election context, it furthermore accommodates for the aforementioned context sensi- 
tivity of populism by considering that the Europeanization of the (national) political arena necessitates an additional-specification of populist elements. Political parties may either allude to a national or European demos and likewise direct their criticism to either the domestic or the EU establishment (see Reungoat, 2010). This level to which people references are made is connected with an overall identification of the general public with the European Union. Hence, this analysis also gives attention to whether there has been the emergence of Pro-European populism (manifested through an explicit appeal to the European community) that might be countervailing putative exclusionary tendencies in the environment of the European financial crisis. News reports about recent crisis developments increasingly convey an image of nations divided into 'debtor' and 'creditor' states, whose peoples are incriminating and vilifying each other. By analysing populist party communication styles in the context of the 2014 EP elections, this study may shed light on whether this perceived rhetoric of exclusivity towards others might be driven by political parties.

This paper is structured as follows. I first describe the three constituting elements of populism and - emerging from the combinations of these elements - identify different types of populist communication. The paper hereby focuses on the transnational nature of the European political field and its implications on populism. Second, I make assumptions concerning party positions and situational factors that determine a party's usage of a particular type and level of populism. Third, the paper describes dependent and independent model variables for the usage of populist communication styles, which is estimated with a series of linear OLS regressions. Fourth, the paper presents descriptive statistics and the main findings from multivariate analysis. Finally, the paper concludes by discussing the implications of the results and by drawing an overall conclusion.

\section{Definition of populism and specification to the European context}

Following Priester (2012), populism is considered as a relational concept, that refers to a relationship between at least two entities and describes an antagonism between friend and foe. At its very core lies the constructed in-group of 'the people', which is opposed to two different out-groups: 'the elites' on a vertical dimension and 'the dangerous others' on a horizontal dimension. In spite of the relative scarcity of systematic methods to empirically measure populism, other scholars have been successful in doing so either by quantitative text analysis (e.g. Pauwels, 2011) or by classical content analysis (Jagers and Walgrave, 2007; Rooduijn and Pauwels, 2011; Rooduijn et al., 2012). Jagers and Walgrave (2007) were among the first to do so, thereby inspiring a number of other studies on populist political communication (e.g. Aalberg et al., 2017; Vasilopoulou et al., 2014; Reungoat 2010). They identify three rhetorical elements of a populist communication style. The first and most important is the reference to the people. Populism appeals to and identifies with the people and justifies its actions in doing so. The second element is an establishment-critique, which emphasises the distance and estrangement between the ordinary people and the corrupt elites 'up there'. The third constitutive element is the rhetorical exclusion of certain societal groups that do not feature the good characteristics of the allegedly homogenous and pure people and are, thus, perceived as dangerous or disruptive for society (Jagers and Walgrave, 2007). 
While some scholars argue that the strategy of exclusion is merely a central feature of radical rightwing populism (e.g. Canovan, 1999; Rooduijn et al., 2012; Taggart, 2000), Jagers and Walgrave (2007) propose that all constitutive elements are considered as features of a political style rather than being bound to a distinct ideology. However, the two claims are not mutually exclusive. Every populist party, regardless of its position on the political spectrum, may apply both anti-establishment as well as exclusive elements, while it might still be the case that either one or the other pole of the spectrum is more likely to apply a certain type of populism. Kriesi and Pappas (2015a, pp. 5-6) point out that it is 'complementary to the definition of populism as an ideology' to perceive populism as a political communication style because the populist ideology 'manifests itself in specific discursive patterns'. ${ }^{1}$ A further aim of this study is to back this argumentation through empirical evidence.

Jagers and Walgrave (2007) distinguish between a thin and a thick concept of populism. In its thick conceptualization, populism is a combination of all three elements, i.e. a political actor's reference to the people and explicitly expressed anti-elite feelings and the exclusion of other individuals or groups (Jagers and Walgrave, 2007). Thinly defined populism consists of only the first element and it is understood as being a necessary pre-condition for populism, as well as a 'normal political style adopted by all politicians from all times' (2007, p. 232). Using words like '(the) public,' '(the) citizens,' '(the) voters,' etc. is described as a standard communication technique and part of the normal political discourse. However, although populism would indeed be unthinkable without any kind of appeal to the people, it is almost impossible for a political actor to reach out to the electorate without displaying closeness to the people. Thus, in the definition used in this analysis, a sole people reference is, in contrast to Jagers and Walgrave (2007), not perceived as a sufficient condition for substantive populism and - due to its lacking in content - does not qualify a discourse as being populist. Because populism is defined as a relational concept, a reference to the people has to be combined with at least one of the other two elements of populist rhetoric.

Following the conceptualization of Roodujin and colleagues (2012) populism is conceived as the property of a message rather than the property of the actor sending this message, which implies that a political actor per se cannot be qualified as being either populist or not populist. Instead, a political actor may be classified as being more or less populist than another political actor depending on how many populist messages the actor has released. By an evaluation of the quantity of populist messages and the different elements of populism comprised within, it is possible to assess whether - in the aggregate - a political actor is using a type of populism that is predominantly thin, thick, rather antielitist, or rather exclusionary. Based on the definition of Jagers and Walgrave (2007) the following types of populism can be distinguished:

Thin populism:

Anti-elitist populism:

Exclusive populism:

Anti-elitist \& exclusive (thick) populism:
(1) people reference

(1) people reference and (2) elite critique

(1) people reference and (3) exclusion

(1) people reference and (2) elite critique and

(3) exclusion 
Furthermore, to analyse different types of populist communication in Europe, it is crucial to recognise that an appeal to 'the people' may be addressed to different target groups depending on the perceived identity of the actor sending the message. The transnational nature of European Integration influences the population's identity perceptions in several ways. While some groups fear a loss of their national identity due to the process of Europeanization, there is in turn evidence for the emergence of a European Identity (e.g. Bruter, 2005; Lutz et al., 2006). As Dechezelles and Neumayer (2010) point out, European Integration transcends the distinction between national and transnational political fields, and the impact of the new European level of representation on national politics cannot be neglected. Populist political actors not only criticise their own national elites but intentionally use EU institutions to illustrate the opposition between 'the people' and 'the elite'. Anti-establishment feelings may thus be addressed explicitly to the national elites or explicitly to the elites of the European Union. Similarly, Kriesi and Pappas (2015b) point out that while populists are usually attacking the national elites, in the course of the sovereign debt crisis the supranational elites or elites from other EU member states may have become the target of populist criticism.

\section{Determinants for the different forms of populism}

\section{Party position on the political spectrum}

Contrary to the common association of populism with parties from the radical Right, Rooduijn and Akkerman (2015) empirically demonstrate that it is not a party's left-right position, but its radicalness that determines the extent of populist rhetoric. According to them, parties on both poles of the political spectrum are inclined to challenge the political elites because they are peripheral vis-à-vis their party systems and can present themselves as diametrically opposed to the allegedly negligent establishment parties. Because anti-democratic and radical parties have largely been deprecated after the end of Second World War, populism has moreover 'become an increasingly attractive alternative' that constitutes a chance of 'finding new, more respectable profiles' and regaining legitimacy among voters (Rooduijn and Akkerman, 2015, pp. 3-4). It can thus be expected that:

H1: Parties settled either on the right or the left pole of the traditional political spectrum use more populist communication styles than mainstream parties.

To understand, however, why varying populist elements are employed within the radical parties' campaigning during the EP elections, it is helpful to analyse their party positions in light of the European integration process. With regards to content, there is a striking overlap between the three elements of populism and the activated issues in the context of the politicization of the EU. In line with globalization, the process of European integration created groups of winners and losers through an enhanced economic, cultural and political competition (Kriesi et al., 2006). In the course of this, a new conflict between integration and demarcation emerged, which according to Kriesi et al. (2006) reflects this antagonism between the two groups of winners and losers. Representing the losers of globalization, left-wing and right-wing extremist parties are the ones most strongly opposed to denationaliza- 
tion in Europe, as a party's support for European integration declines with its distance from the center of the political spectrum (Hooghe et al., 2002; Taggart, 1998).

The radical Left's deeply entrenched opposition to the opening up of borders basically derives from the economic contradictoriness of their policy goals to the market-liberal nature of the European project (Kriesi et al. 2006; Heine 2010). The integration process weakened the authority of the nation states (e.g. Börzel and Risse, 2000; see Hooghe et al., 2002) and gradually suppressed, loosened, and disrupted arrangements, such as the various designs and redistribution policies of national social welfare states. Equivalent new arrangements at the supranational level, in contrast, were not always created in a sufficient way (Bartolini, 2005). The design of the European Treaties is favouring marketdeepening policies while simultaneously impeding measures for market-correction and are, therefore, incompatible with the policy goals of the radical Left (Hooghe et al., 2002; e.g. Scharpf, 1999). With regard to the demarcation/integration conflict, peripheral actors on the Left are thus highly protectionist on a socio-economic dimension (Kriesi et al., 2006). In addition, the attenuation of the nation state's authority also reduced the impact of national participation forms in the collective decisionmaking process (Heine, 2010). As a matter of principle, parties from the radical Left perceive the EU as 'an imperialist power contradicting the basic principles of autonomy and national selfdetermination' and a 'vehicle for elite and great power domination' (Halikiopoulou et al., 2012, p. 512). Therefore, these parties resolutely criticise the democratic deficit of the European Union and since the process of European integration has been a project driven by elites from its very start (Taggart 1998) - their critique is directed to the established political class held responsible for these developments.

Political parties from the radical Right too complain about the EU's democratic deficit, accuse the EU elites of corruption, and blame EU institutions for inefficiency. However, the radical Right's basic orientations are traditionalism and anti-immigration, and their opposition to the EU is based on an exclusive, ethnic nationalism (Halikiopoulou et al., 2012). The construction of European nation states in the twentieth century forged strong cultural links amongst their members and established cultural boundaries through the formation of national identities (Heine, 2010). With the beginning of the European integration process, these boundaries have been softened and have called into question the cultural homogeneity of the member states. Radical right-wing parties fear the loss of national identity and see themselves as defending national community and culture against foreigners (e.g. Kitschelt and McGann, 1995). With respect to the demarcation/integration conflict, they are therefore distinctly protectionist on a cultural dimension (Kriesi et al., 2006). Their objection to the opening up of borders in the course of European integration is strongly linked to their opposition to apprehended immigration on the principle of free movement of persons and the prospective enlargement to the East. For fear of any kind of social and cultural competition, parties from the radical Right are not only demanding a re-establishment of national border controls, but also stricter border controls at the EU's outer borders to prevent immigration from third countries (see Hooghe et al., 2002). Thus, it can be expected that: 
$\mathrm{H} 2$ : In the populist communication of radical parties from the Left, an anti-elitist type of populism is predominant while the element of exclusion is neglected; in addition to the classical anti-elitist type of populism, radical parties from the Right apply the element of exclusion more visibly (i.e. an exclusive or a thick type of populism).

To what level, however, do the political parties allude when they apply these populist elements? To what particular demos an appeal to 'the people' may be addressed depends on the identity perception of the actor sending the message. According to Herrmann and Brewer (2004), individuals hold multiple identities that may relate to each other in different ways. If an individual belongs to several distinct groups with non-overlapping memberships, this person's group identities are essentially separate or exclusive. Furthermore, a nested identity configuration is possible if an individual of a smaller community is simultaneously part of a larger community and identifies with both of them. With regard to the European Union, an individual may feel both as a citizen of its nation state and as a citizen of the EU, thereby featuring an inclusive European identity. In the European context, people may also simply feel as citizens of their own nation state without any sense of belonging to the European Union at all, holding an exclusive national identity. Accordingly, political parties are expected to represent these identity perceptions of their electorate. McLaren (2007) further analysed the connection between concerns about the loss of national identity and perceptions of EU institutions. In her analysis, she points out that an exclusive national identity has a significant effect on hostility to EU institutions and significantly enhances opposition to the European integration project. In this sense, exclusive national identity perceptions may in fact bring supranational elites within the focus of the populist establishment critique. Corresponding to their basic orientation towards ethnic nationalism, radical right parties mainly represent a constituency with an exclusive national identity. Therefore, it is expected that:

H3a: Radical parties from the Right predominantly apply a populist communication style comprising an appeal or reference to their own national community. Their elite critique is furthermore expected to be predominately directed at the EU elites.

In contrast, mainstream parties tend to be pro-European and supportive of the European integration process; thus, they are expected to represent an electorate that is likely to hold an inclusive European identity. However, radical parties from the Left, albeit being opposed to the current arrangement of economic integration, are of a very pro-European nature as well, as their vision of Europe is based on a predominantly communitarian perspective. Their scepticism with regard to denationalization is based on a civic nationalism against perceived imperialist powers, but it is nonetheless inclusive and volitional, and it does not emphasise the homogeneity of the own nation (Halikiopoulou et al., 2012). First and foremost, the radical Left considers a moral community - and this might as well be Europe - essential for the functioning of a democratic entity and a redistributive social system (Heine, 2010). However, despite the fact that parties from the radical Left $d o$ hold distinct identity perceptions, Heine's content analysis (2010) of party manifestos from the French radical Left revealed that left-wing critiques against the European Union are predominantly based on arguments concerning the socioeco- 
nomic or political nature of the EU, while identity matters play a secondary role within their discourse on the European project. With regard to their populist party communication, it is thus expected that:

H3b: Radical parties from the Left predominantly apply a populist communication style comprising a people reference directed to 'the people' in general, without explicit appeals to specific target groups. If, however, their people reference is addressing a particular demos, it is expected that they are predominantly appealing to the European community.

\section{Situational party- and country-specific factors}

Ideological and policy stances of political parties are party-inherent and are more or less stable over time. However, certain situational or temporary factors may additionally influence the extent and type of populism a party applies. During election campaigns, governing parties are part of the establishment themselves, and - being in constant proceedings with the EU elites due to their role as representatives of their country - it stands to reason that compared to opposition or non-parliamentary parties they are more likely to avoid populist communication styles while in office. The findings of Kriesi \& Pappas (2015b) that populist parties tone down their messages when presumably or effectively in power are consistent with these thoughts. However, this does not mean that ruling parties are not producing any elite critiques at all. In any case, one must keep in mind that governing parties are performing as national elites and, hence, do not have any incentive to criticise themselves during an election campaign. In consideration of this rationale, it is expected that:

H4: Parties in government use less populism in general, and in particular they apply significantly less criticism on the national elites than parties without government participation.

Apart from government participation, some external forces may influence a country's climate of political communication as a whole. Populism seems to be the product of crisis, mobilization, and confrontation. The idiosyncratic shape of the European sovereign debt crisis entailed additional and more specific points of criticism to correspond with the three elements of a populist communication style. European and domestic elites have been under attack for unpopular crisis management arrangements, and for backing the temporary implementation of technocratic governments in Greece and Italy, which fundamentally questioned the national sovereignty of countries. The crisis has demanded increased solidarity between the European member states and has evoked national cleavages between 'donor' and 'debtor' countries, while the adverse state of the economy has generated and intensified feelings of ostracism and exclusion (Hartleb, 2012; Kriesi and Pappas, 2015a). In line with these considerations, the analysis of Kriesi and Pappas (2015b) also largely supported that economic and political crises have a reinforcing effect on populism. Thus, it is expected that:

H5a: Parties in countries heavily affected by crisis are prone to apply more populism in their party communication, and in particular they are using the exclusive element more visibly than parties within a less crisis-ridden environment. 
As Brubaker (2011) points out, the European financial crisis has already generated plenty of nationalism on the rhetorical level. Based on the urge to protect the national community in view of putative economic threats from outsiders, economic crises not only provoke and intensify exclusive feelings, they are often associated with a great deal of nationalism. With regard to the level of populist party communication, it is therefore expected that:

H5b: Parties from crisis-hit countries more visibly appeal to the national community compared to parties within countries that are only mildly affected by crisis.

Two approaches were made to verify these assumptions. First, I analysed party-specific frequency distributions of populist elements in each party's press releases. Thus, it was possible to compare national characteristics of populist party communications, while at the same time gaining insight into party-specific variations in populist communication styles within a country. In order to statistically test the assumptions, linear Ordinary Least Squares regression was used to calculate the impact of each of the independent variables on the use of different populist communication styles, thereby illustrating an overall trend of party position effects on populism apart from country-specific appearances.

\section{Measurement}

\section{Data source and measurement of populist communication}

To test the assumptions discussed above, press releases from all political parties that reached more than $3 \%$ in the last national or European elections were collected for Germany, Austria, Greece, and France for the 12-week period prior to the 2014 European elections. Only press releases that referred to the terms $E U$ and/or Europ*/europ* and/or relevant acronyms of EU actors, institutions or policies (f. ex.: EP, EZB, ESM etc.) at least twice were included in the analysis in order to limit coding material to topics relevant to the context of EP election campaigns. Thereby, a full survey of relevant press releases $(\mathrm{N}=1934)$ from a total of 28 political parties was obtained and subsequently analysed through a quantitative content analysis. The statement of the actor who published the press release (which can be identified either as a party or a specific political actor) was considered as the unit of analysis.

In order to encompass populism, the three variables of people reference, elite critique, and exclusion were constructed based on the definition of Jagers and Walgrave (2007). ${ }^{2}$ To take into account the specific context of a European political area, the variables were then further specified so as to precisely assess the target of the appeal, criticism, or exclusion. The first step was to evaluate whether there was an explicit reference to the people in the party's statement. If the sender was mentioned within the press release as a specific political actor, coders were asked to specify whether this was a national or EU actor and whether he directed his appeal explicitly to a national, European or unknown community. To qualify as a reference to the people, the actor's statement had to fulfil two criteria: the statement had to feature the explicit mentioning of a specific population or population group (f. ex. 'the Greek,' 'the nation,' 'Europeans.' 'tax payers,' 'voters,' etc.) and, through his statement, the actor had to either advocate for or explicitly side with these people or had to support their concerns or claims. A people 
reference was also coded if the actor spoke in the name of the mentioned population (or group) by allegedly expressing this people's attitude.

Example: explicit mentioning of and advocacy for a specific population group ${ }^{3}$

'We simply cannot go on like this if we are to even begin the task of restoring the living standards and community cohesion available to millions of hardworking British families.' (Nigel Farage of UKIP, 22 May 2014)

Example: explicit mentioning of a specific population group and allegedly expressing this groups attitude

'Voters are sick and tired of the same old business-as-usual politics and they are voting Green because they know that a Green vote is a vote for real change for the common good. They are realising we are the party offering the most just and sustainable future for the whole of Britain and the planet.' (Natalie Bennett of The Greens, 24 May 2014)

If a people reference could be identified within the press release (and only then), the subsequent variables of elite critique and/or exclusion were coded if they appeared in the text. Following Jagers and Walgrave (2007), the anti-establishment variable took into account any criticism towards political elites, specific policies and/or polities, or the system as a whole. Furthermore, critiques directed at economic or cultural elites - e.g. central banks, intellectuals, or the media - were factored in. Coders were asked to specify whether the target of criticism was either the establishment of the speaker's own country, the establishment of another specific EU-member state, the EU-elites in general or any other/unspecified establishment. Elite critique was understood as a negative evaluation of the establishment, either in terms of discreditation or accusations, or - in cases where there were no negative attributions - in the form of denied positive attributes; for example, an explicit rejection of praise or appreciation for the establishment.

Example: criticism towards political elites in terms of accusation and negative evaluation of governmental performance

'David Cameron has broken his solemn promise to the British people on one of the most important political issues. And he has done so because he refuses to take back control of our borders in respect of more than 400 million people from more than two dozen countries on continental Europe.' (Nigel Farage of UKIP, 22 May 2014)

Example: criticism towards political elites in terms of discreditation and accusation

'After years of being ignored by the out-of-touch political elite, after years of watching our Green and Pleasant Land turned into a bankrupt, crime-ridden, Third World slum - it's time to hit back and tell the greedy, useless politicians exactly how you feel!' (Press Release of the BNP, 22 May 2014) 
The exclusion variable asked whether the actor's statement followed an exclusion strategy by explicitly criticizing one or multiple nations or groups in society - namely immigrants, asylum seekers, or minorities. This variable searched for criticism addressed to a nation or a group in society as a whole and excluded criticism directed solely to a nation's establishment (i.e. its government or other elites). Again, the actor's statement had to explicitly mention a population, nation, or group in society (although, this time, the actor himself could not be part of that group). This exclusive criticism could consist of several means for negative attribution, such as verbal discreditation, stigmatization, and/or degradation. It was furthermore perceived as exclusion if that population group or nation was blamed, accused, or described as a threat, menace, or source of harassment for the community.

\section{Example: exclusive criticism on immigrants by describing them as a harassment for the national community}

'[...] - it's time to hit back and tell the greedy, useless politicians exactly how you feel! Just remember all the times you've been so angry at the latest scandal of illegal immigrants getting benefits and legal aid while our people are left to rot.' (Press Release of the BNP, 22 May 2014)

The content analysis has been carried out by three native coders for press releases from Germany and Austria, two native coders for France and one native coder for Greece. All coders were trained in English to ensure a consistent training procedure. A short introduction acquainted coders with the concept of populism and the specifications of the project's variables. Each variable's researcher-coder reliability was tested according to the Krippendorff's $\alpha$-coefficient by conducting a reliability test (also in English), which included 25 press releases. By matching the results of each coder to a mastercoding scheme (which I specified in advance), it was possible to illustrate how adequate coders afield were able to assess the concepts in the same way as they are understood by the researcher. For the formal variables (i.e. country, date of publishing, and sending party), all coders achieved average Krippendorff's $\alpha$ values between 0.83 and 1.00. Furthermore, reliability values of the Greek and French coders were also satisfactory for the three populism variables. On average, the two French coders achieved Krippendorff's coefficients of $\alpha=0.85$ for people reference, 0.76 for elite critique, and 0.84 for the exclusion-variable. The Greek coder obtained Krippendorff's values of $\alpha=0.93$ for people reference, 0.73 for elite critique, and 0.87 for the exclusion-variable. However, the three German-speaking coders achieved sufficient averaged coefficients for people reference $(0.91)$ and elite critique (0.76), but the average Krippendorff's $\alpha$ value for the exclusion-variable turned out to be too low (0.44) even after a second reliability test was conducted. Therefore, as to not delay the start of the coding process for the broader project, I decided to code this variable ex post by myself. The intracoder reliability test I conducted resulted in an adequate Krippendorff's $\alpha$-coefficient of 0.89 . 


\section{Dependent variable}

I created seven scales in total to assess the parties' use of various types of populist communication styles and the elements comprised within. The percentage value of press releases that contained populism (i.e. press releases that featured a people reference and an anti-elitist and/or exclusive statement) in proportion to the total amount of all press releases a party had published within the 12-week period prior to the EP elections was assigned to each party, respectively, to create a general scale for populist communication popcom. In the same line, I created scales for an anti-elitist and for an exclusive populist communication style by assigning to each party the percentage value of press releases containing anti-elitist or exclusive populism, respectively, in proportion to the total number of press releases per party. Populist communication was considered anti-elitist if a press release contained a people reference and an anti-establishment stance without any exclusive element. A communication style was considered exclusive if an exclusive stance could be identified in combination with a people reference, irrespective of an additional elite critique or not. ${ }^{4}$ Two more scales were generated to assess how many populist press releases featured a people reference directed to the national people (NATpop) and to the EU people (EUpop), respectively. Here, too, the reference point for the assigned percentage values was the total number of a party's published press releases. However, for these two scales, only the people references and their addressees were of primary interest and not the specific targets of elite criticism; it was mandatory that all press releases featured an additional anti-establishment and/or exclusive element to exclude 'thin populism' from the scale. Eventually, two scales were created to determine how many of the populist press releases featured criticism of the national elites (NATantiest) and of the European elites (EUantiest), respectively. ${ }^{5}$ Neither the specific direction of the people reference nor the existence or absence of any exclusive element was relevant for these two scales. In contrast to the other populism scales, each party was assigned the percentage value of press releases that contained elite critiques on the respective target in proportion to a party's amount of published press releases containing (any kind of) elite critique.

\section{Independent variables}

As measures for a party's ideological position and its positioning on European integration, I used data from the 2014 Chapel Hill expert survey (see Bakker et al., 2015), which relies on placements by academic experts. The following item was used to assess the Left/Right placement in the political spectrum: 'Please tick the box that best describes each party's overall ideology on a scale ranging from 0 (extreme Left) to 10 (extreme Right).' For the analysis, I then created three dummy variables so as to be able to compare populist communication styles not only between left- or right-wing parties but also more generally between fringe and center parties. I classified parties featuring values $\leq 2.5$ as leftwing; parties featuring values $\geq 7.5$ as right-wing, and parties featuring values ranking from 2.6 to 7.4 as center. To control for government participation, I included a dummy variable for parties in office in the multivariate analysis, thereby relying on the Parliaments and governments database ParlGov, which includes data on elections and cabinets in established democracies since 1945 (see Döring and Manow, 2015). ${ }^{6}$ 
I separated the four countries under study into 'crisis-spared countries' and 'crisis-hit countries' and included a dummy variable in the analysis. Germany and Austria are considered as 'crisis-spared,' while France and Greece are considered as 'crisis-hit'. As a proxy for crisis-affectedness, I primarily used macroeconomic data from Eurostat for the last three years $(2012$ - 2014) such as a country's youth unemployment and unemployment rate, the percentage of growth in the nation's real gross domestic product (GDP) per capita, a country's government deficit/surplus, and its government debt as a percentage of GDP. ${ }^{7}$ The effects of the crisis have been fairly modest for Germany and Austria. Their 3 -year average of almost all macroeconomic indicators lie above the respective average values of the EU-28. However, while it is obvious that Greece was hit particularly hard, macroeconomic indicators for France show a rather mild immediate impact of the crisis at first sight. Thus, even though almost all indicators for France do lie below the EU-28 average, its classification as a 'crisis-hit' requires further justification.

National accounts do not fully reflect the serious structural weakness of France's economy, which was relentlessly exposed by the economic downturn of the crisis (see Betz, 2015). In addition to an increasingly adverse balance of trade and rising socio-economic inequality, French companies were highly indebted, showed low profitability rates, and limited capacities for innovation, which resulted in an overall substandard competitiveness of the French economy (European Commission, 2014). While the country initially was less affected by the crisis than other large euro area economies, its recovery proved to be difficult. This became evident in the two years of near stagnation after 2012, an unemployment rate that got stuck above 10 percent and an increasing level of public indebtedness (European Commission, 2014; IMF, 2014). This major economic vulnerability of France had adverse psychological effects on large segments of the population (Betz, 2015). A pervasion of the French society by a 'general sense of economic malaise' (Pappas and Kriesi, 2015, p. 310 f.) eventually resulted in a profound decline of public trust in political institutions and representative democracy in general. Not only on account of the country's adverse macroeconomic prospects, but also because of this perceived sense of malaise and the consequential political malfunction I classified France as a 'crisis-hit' country highly susceptible to populist mobilisation.

\section{Analysis}

\section{Frequency distributions}

A party-specific analysis of frequency distributions per country shows that both fringe and mainstream parties make use of populist communication styles in their press releases (Figure 1). In all four countries, however, the usage of populism seems to be slightly more pronounced by parties on the fringes of the political spectrum. Within the populism of radical parties from both poles of the political spectrum, the elements of people reference and elite critique are predominant. Furthermore, the exclusion element seems to be a constituent that is specific to radical right-wing populism. 
Figure 1. Percentage of populist press releases with anti-elitist and exclusive elements per party.

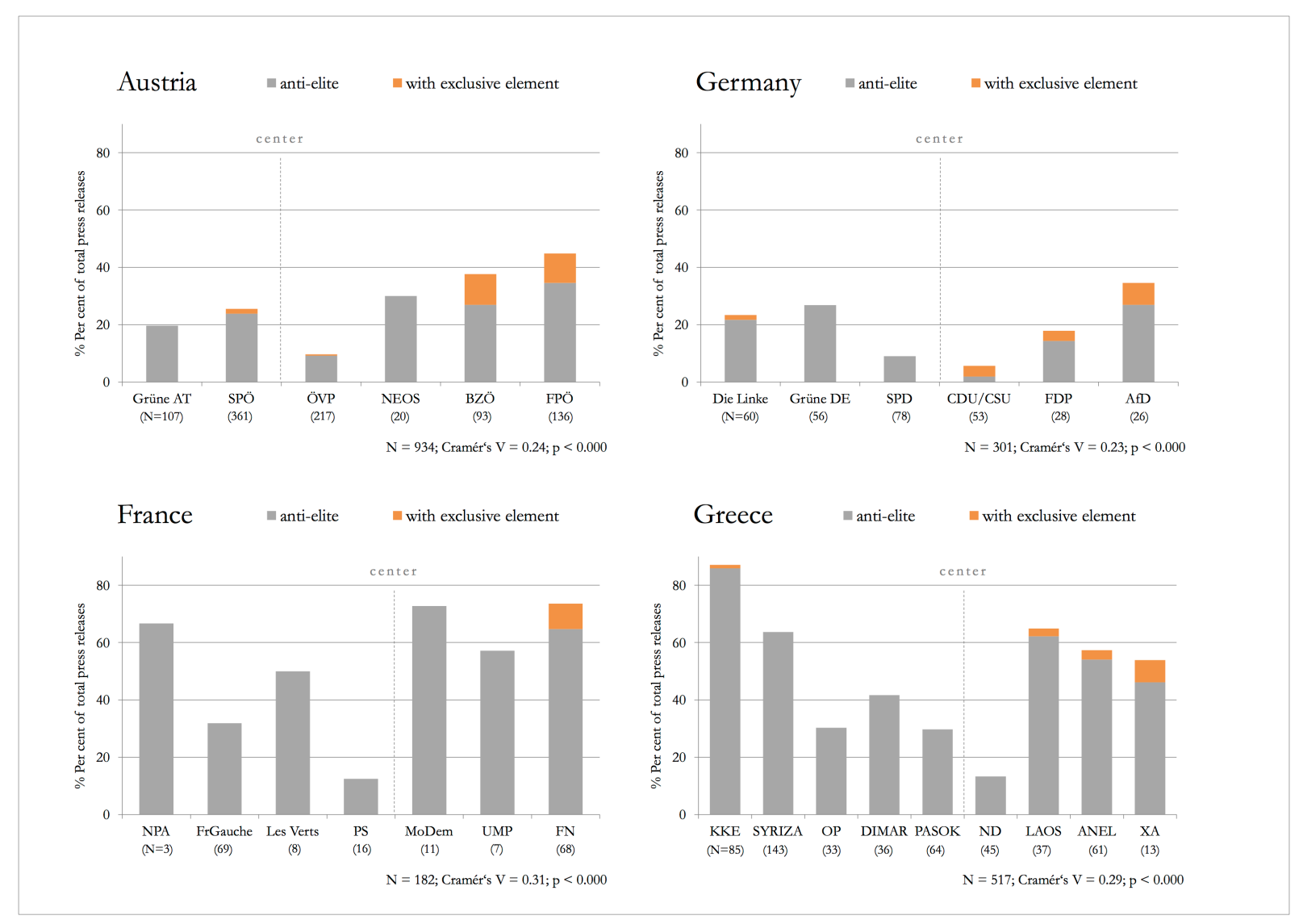

Notes: Parties are arranged from the left to the right according to their ideological position on the political spectrum (country-specific center ground is indicated).

However, not only parties from the radical Right make use of an exclusive strategy, since the element also appeared in press releases from mainstream parties. Exclusive stances were found in the party communications of the Austrian social democrats SPÖ and the conservative Austrian people's party ÖVP, in press releases of the German conservative Christian Democratic Union CDU and the German liberal party FDP, and some exclusive elements even appeared within populist press releases from the radical Left, including the German 'die Linke' and the Greek communist party KKE. These findings are in line with Jagers and Walgrave's (2007) claim that, in general, every party on the political spectrum may apply each of the three populism elements. These data also empirically confirm the proposition that exclusion is a rather prevalent feature of the radical Right's populism. Furthermore, the cross-country comparison of the usage of populist party communication shows that the level of populism is considerably higher in crisis-hit France and Greece than in Austria and Germany. As shown in Figure 2, both German and Austrian radical left and mainstream parties direct their populist communication to the European rather than to the national community. 
Figure 2. Percentage of populist press releases with explicitly addressed demos (national vs. EU) per party.
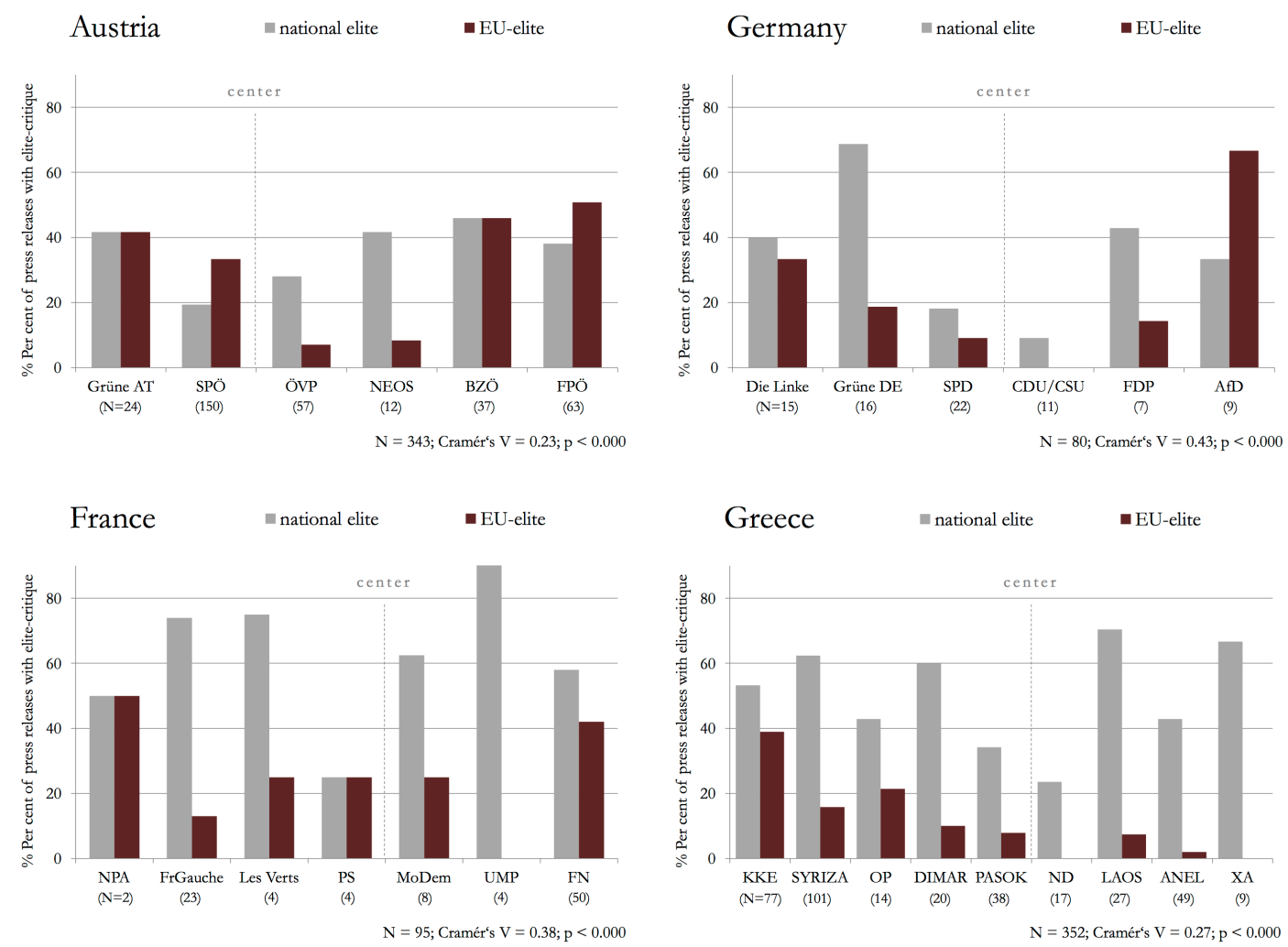

Notes: Parties are arranged from the left to the right according to their ideological position on the politi- cal spectrum (country-specific center ground is indicated); additional percentages ('yes, a reference to an unspecified/other people') are not pictured for reasons of readability.

The exception is, however, the conservative party in Austria. While being basically EU-friendly and representing an inclusive European identity, the ÖVP is predominantly addressing its national community when applying populism. In the same way, the French conservative party Mouvement Démocrate is predominantly appealing to the national people, while the Greek Nea Dimokratia does not refer to a European community at all. Both in Greece as well as in France, there is a strong overall national focus among almost all parties. All appeals to the people in the two countries are primarily directed to the national population, regardless of a party's position on the political spectrum. In matters of elite critique (Figure 3), Greek parties more often criticise the establishment of the European Union the more left they are on the political spectrum. In Austria, Germany, and France, fringe parties seem to criticise EU elites more than the mainstream parties. However, a more specific pattern regarding the application of elite critique cannot be clearly distinguished from the frequency distributions below. 
Figure 3. Explicit target of establishment-critique in populist press releases per party.

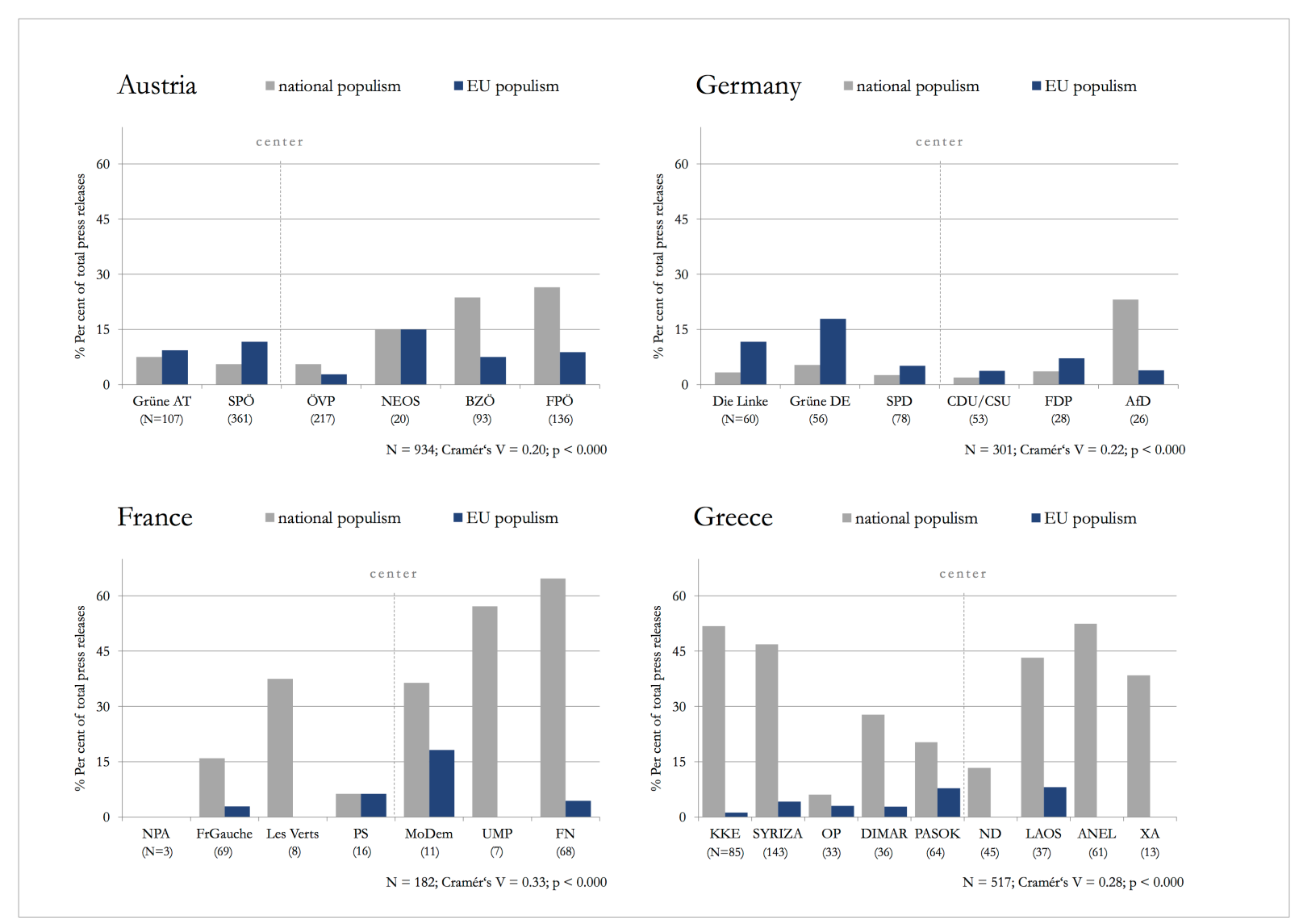

Notes: Parties are arranged from the left to the right according to their ideological position on the political spectrum (country-specific center ground is indicated); additional percentages ('yes, against the establishment of other specific EU member state(s)', 'yes, against other / unspecified establishments(s)') are not pictured for reasons of readability.

\section{Multivariate analysis}

As indicated in Table 1, center parties score 24.48 percentage points lower on the scale for populist party communication compared to fringe parties. This speaks in favour of $\mathrm{H} 1$, which claims that the usage of populism is more pronounced on the fringes of the traditional political spectrum. However, this effect ceases to be significant if one takes into account a party's policymaking position (i.e. being in office or not) and additionally differentiates between the two crisis-hit and the two crisis-spared countries. ${ }^{8}$ It is thus impossible to conclusively confirm hypothesis 1 , although it is probable that the significant effect eventually dissolves due to the insufficient number of data points $(n=28)$, given the four explanatory variables. Being a radical right party appears to have a highly significant (albeit rather weak) effect on the usage of populism with an exclusive element. Fringe parties from the Right score almost six percentage points higher on the scale for an exclusive populist communication style than extreme left and center parties. These findings are in line with the assumptions of $\mathrm{H} 2$ that radical parties from the Left predominantly use an anti-elitist type of populism while the exclusive element is neglected; whereas parties from the radical Right apply the element of exclusion more visibly and in addition to the classical establishment critiques in their populist communication. 
Being a party on the right pole of the political spectrum has a significant and strong effect on the use of a nationally oriented populist communication style. Radical right parties are 24.85 percentage points higher than radical left parties in terms of using populism featuring a people reference directed to their own nation. However, compared to other parties, parties from the extreme Right do not, as expected, direct significantly more elite critiques to the EU establishment, which is why H3a is only partly confirmed. Furthermore, the usage of populism featuring an appeal to the people of the European Union does neither significantly differ within radical parties, nor between fringe and mainstream parties. This means that H3b, claiming that parties from the radical Left might be appealing to the European community more visibly in comparison to radical right parties, cannot be confirmed.

Table 1. Predictors of the Usage of Different Populist Communication Styles.

\begin{tabular}{|c|c|c|c|c|c|c|c|c|}
\hline & \multirow{2}{*}{$\begin{array}{l}\text { Model } 1 \\
\text { Popcom }\end{array}$} & \multirow{2}{*}{$\begin{array}{l}\text { Model } 2 \\
\text { Popcom }\end{array}$} & \multicolumn{2}{|l|}{ Type } & \multicolumn{4}{|l|}{ Level } \\
\hline & & & Anti-elitist & Exclusive & NATpop & EUpop & NATanties & EUanties \\
\hline Center & $\begin{array}{l}-24.48 * \\
(9.236)\end{array}$ & $\begin{array}{l}-4.762 \\
(8.019)\end{array}$ & $\begin{array}{l}-3.824 \\
(7.975)\end{array}$ & $\begin{array}{l}-0.938 \\
(1.198)\end{array}$ & $\begin{array}{l}6.813 \\
(6.931)\end{array}$ & $\begin{array}{l}4.442 \\
(2.611)\end{array}$ & $\begin{array}{l}9.696 \\
(7.337)\end{array}$ & $\begin{array}{l}-14.34 \\
(9.845)\end{array}$ \\
\hline Right-wing & $\begin{array}{l}2.503 \\
(10.22)\end{array}$ & $\begin{array}{l}7.015 \\
(7.559)\end{array}$ & $\begin{array}{l}1.586 \\
(7.517)\end{array}$ & $\begin{array}{l}5.429 * * * \\
(1.129)\end{array}$ & $\begin{array}{l}24.85 * * * \\
(6.533)\end{array}$ & $\begin{array}{l}-0.651 \\
(2.461)\end{array}$ & $\begin{array}{l}6.967 \\
(6.916)\end{array}$ & $\begin{array}{l}-5.004 \\
(9.280)\end{array}$ \\
\hline Government & & $\begin{array}{l}-21.91 * * \\
(7.393)\end{array}$ & $\begin{array}{l}-22.24 * * \\
(7.351)\end{array}$ & $\begin{array}{l}0.332 \\
(1.104)\end{array}$ & $\begin{array}{l}-11.09 \\
(6.389)\end{array}$ & $\begin{array}{l}-4.706 \\
(2.407)\end{array}$ & $\begin{array}{l}-33.57 * * * \\
(6.763)\end{array}$ & $\begin{array}{l}-8.671 \\
(9.075)\end{array}$ \\
\hline Crisis-hit & & $\begin{array}{l}21.66 * * * \\
(5.583)\end{array}$ & $\begin{array}{l}24.07 * * * \\
(5.552)\end{array}$ & $\begin{array}{l}-2.408 * * \\
(0.834)\end{array}$ & $\begin{array}{l}20.91 * * * \\
(4.825)\end{array}$ & $\begin{array}{l}-4.381^{*} \\
(1.818)\end{array}$ & $\begin{array}{l}18.20 * * \\
(5.108)\end{array}$ & $\begin{array}{l}-14.84^{*} \\
(6.854)\end{array}$ \\
\hline _cons & $\begin{array}{l}50.48 * * * \\
(7.728)\end{array}$ & $\begin{array}{l}32.43 * * * \\
(7.316)\end{array}$ & $\begin{array}{l}29.95 * * * \\
(7.275)\end{array}$ & $\begin{array}{l}2.480^{*} \\
(1.093)\end{array}$ & $\begin{array}{l}3.231 \\
(6.323)\end{array}$ & $\begin{array}{l}7.479 * * \\
(2.382)\end{array}$ & $\begin{array}{l}38.57 * * * \\
(6.693)\end{array}$ & $\begin{array}{l}41.14 * * * \\
(8.981)\end{array}$ \\
\hline $\mathrm{N}$ & 28 & 28 & 28 & 28 & 28 & 28 & 28 & 28 \\
\hline adj. R-sq & 0.293 & 0.622 & 0.616 & 0.646 & 0.627 & 0.278 & 0.626 & 0.154 \\
\hline
\end{tabular}

Notes: Non-standardized OLS coefficients; standard errors in parentheses; omitted category is left-wing, all the regressions have high tolerance values $(>0.40)$ and low values for $\operatorname{VIF}(<2.5)$, indicating that there are no severe multicollinearity effects present; $* \mathrm{p}<0.05 ; * * \mathrm{p}<0.01$; $* * * \mathrm{p}<0.001$

The results that ruling parties are almost 22 percentage points lower on the overall populism scale than opposition or non-governing parties are in line with H4. In matters of applying anti-elitist populism, the negative effect of being in government is highly significant. As expected, parties in power score much lower on the scale for criticism of national elites than non-governing parties. The overall level of populist party communication appears to be higher in the two countries that are more heavily affected by the crisis, which is indicated by the fact that Greek or French parties score higher on both the general and the anti-elitist scale for populism compared to Austrian or German parties. However, contrary to expectations stated in H5a, these parties obviously use significantly less exclusive elements within their populism, irrespective of their crisis-ridden environments. Eventually, there are some reasons in favour of $\mathrm{H} 5 \mathrm{~b}$, because French and Greek parties apply more nationally oriented pop- 
ulism compared to Austrian and German parties, regardless of their ideological or governmental position. This significant effect, together with a strong positive coefficient for the usage of national establishment critique, affirms the trend towards a nationally oriented populism in the environment of a crisis-hit country. However, previous studies have shown that both French and Greek parties have already been inclined to employ a nationalist rhetoric before the crisis (e.g. Reungoat, 2010; Halikiopoulou et al. 2012). On this account, only a systematic analysis over time will be able to clarify whether or not the observed type of nationally oriented populism has actually been enhanced by the crisis. In any case, the results at hand concerning the effects of the crisis have to be handled with caution, as will be discussed more precisely in the next section. ${ }^{9}$

\section{Conclusion}

Many of the aforementioned assumptions are confirmed, yet this study has limitations. One limit is the low number of countries and their respective political parties under analysis. It might be helpful to analyse additional and more diversified countries in future studies in order to confirm and reinforce the results. The differences between Austria and Germany vs. France and Greece, for example, are above all assumed to root in the countries' affectedness from the crisis. Yet it is possible that differing populist communication styles between the two German-speaking and the two Mediterranean countries might stem from unconsidered, country-specific parameters. The analysis of Vasilopoulou and colleagues (2014, p. 389), for instance, reveals that populism is a defining feature of the Greek political system and 'at the heart of Greece's endemic domestic weakness'; therefore, populist communication styles are not necessarily a consequence but also a potential source of the country's economic challenges. Moreover, the causes and consequences of the crisis varied considerably among crisis-hit countries, as did the rise and nature of their parties' populist rhetoric. Therefore, further comparative research is needed, which is also focusing on an analysis of variation within these countries. On the basis of the results at hand, it is thus not possible to conclusively assess whether or not a crisis-ridden environment actually fosters populist rhetoric. For a start, however, this cross-country comparison tentatively supports former research on the assumption that economic (and political) crises are influencing populist communication.

Apart from this, it is nevertheless possible to fathom some of the questions asked at the commencement of this article. What kind of party characteristics and situational factors did influence the selection of specific populist communication styles in the course of the 2014 EP election campaign? As a first finding, populist party communication appears to be more pronounced on the fringes of the political spectrum if compared to populism used by mainstream and government parties. These findings are in line with previous findings on the relationship between radicalism and populism. However, as shown in the descriptive results, it is not only the fringe parties that are inclined to employ a populist rhetoric. There is also a considerable extent of populism among mainstream parties, particularly in France and Greece, where populism is widespread among almost all political parties. In the case of Greek, these results clearly coincide with the work of Pappas (e.g. 2014) on the mainstream PASOK, which started to follow a distinct populist course since the 1980s and, through populist contagion to 
other major parties, eventually transformed the entire party system into a so called 'populist democra$c y^{\prime}$.

Across all countries and parties, populism is basically composed of a reference to the people and an establishment critique, while the element of exclusion is used significantly more often among populist parties from the Right than among parties in the center or on the left pole of the political spectrum. While this implies that exclusion is a central feature of populism from the extreme Right, the analysis of party-specific frequency distributions also points out that it is not solely a feature of the radical Right's populist rhetoric, but it is a principle applied by various parties across the political spectrum. By showing that specific types of populism might be linked with ideologies while the elements of a populist communication style are not strictly bound to specific party positions, this study empirically confirms the complementarity of the perceptions of populism as an ideology and as a political communication style.

Furthermore, radical right parties more frequently target the national community when applying a populist communication style. Both findings are rooted in the extreme Right's ideological orientation towards ethnic nationalism and the corresponding exclusive identity perceptions represented by this party family. However, while the results of this study allow for an explanation of the nationalistic aspect of populism it remains rather unclear under what conditions political parties are selecting a populist communication style directed to the European community. Multivariate analysis did not reveal any significant difference between party families pertaining to the usage of appeals to the European demos. However, party-specific frequency distributions suggested that a pro-European populism in this vein seems to be existent among most of the political parties, and it appears to be slightly more pronounced among parties representing an inclusive European identity. The emergence of such a bordertranscending populist communication style in turn may actually arouse and enhance a European sense of community, which is of fundamental importance in order to legitimate any ambition for a deeper political integration of the EU member states.

With regard to the element of exclusion, the low numbers of exclusive statements found in the data material were far too small for a meaningful quantitative analysis of the specific targets of the parties' ostracism. ${ }^{10}$ Only 5.5 percent of all the press releases containing a people reference also feature an exclusionary stance. Although around 70.8 percent of this exclusivity originates from radical right parties, even in the extreme Right's discourse the exclusive element is applied only to a minor degree. Meanwhile, these results are not all that dissimilar from the findings of Jagers and Walgrave (2007, p. 331): While the Belgian radical right party Vlaams Blok is accountable for 71.2 percent of exclusivity, only about 9.2 percent of all the population mentioning passages analysed in their study were negative evaluations of specific population categories. In any case, one of the key findings of this study is that, contrary to intuitive expectations, the rhetoric of exclusivity towards other groups barely takes place within populist party communication.

The same could be said for the sovereign debt crisis enforcing rhetorical exclusion of European member states amongst political parties. The putative cleavage between 'donor' and 'debtor' countries is more likely emanating from sensation-seeking mass media, whereas political parties are not exploit- 
ing this mean of divisiveness within their political discourse. First and foremost, political parties pass their electorate's frustration and enragement on to domestic and European elites by means of fundamental establishment critiques. As a rather optimistic conclusion, one could therefore say that, despite the rising success of populist communicating parties during the 2014 EP elections, social cohesion within the European Union might be less endangered than the daily news coverage would cause one to believe.

\section{Notes}

1. While the definition of populism as a political communication style is complementary to the definition of populism as an ideology, it is worth mentioning that most scholars do not understand populism as a complete ideology. Cas Mudde's (2004) definition of populism as a 'thin-centred' ideology with its ability to attach itself to other host ideologies belongs to the most widely cited perceptions of populism. However, for an interesting discussion of whether or not populism should be defined as an ideology at all or rather be conceptualised as a discourse (or populist frame) see Aslanidis (2015).

2. The general project codebook with a full description of the variables' design is available from the author upon request.

3. All examples are taken from UK press releases that were employed during the coder training.

4. Thus, a statement also qualified as exclusive if it was featuring all three elements of populist rhetoric (i.e. thick populism), as the combination of a people reference in combination with solely an exclusive stance turned out to be very rare (6 out of 1934 press releases).

5. Descriptive statistics for each scale are provided in the Appendix.

6. The subsequent analysis has also been conducted for an operationalisation which combines a party's ideological positon and its government status in the categories 'left-wing', 'right-wing', 'centre-government', and 'centre-opposition'. In essence, the results of these alternative calculations do not differ from the original ones and are provided in the online supplementary information.

7. A detailed list of all considered macroeconomic data is provided in the online Appendix.

8. Because this analysis is dealing with a very small sample size, single cases (here parties) may have a high influence on the regression estimates. Against this background, I conducted regression diagnostics for each model and used Cook's D as a global measure of influence in order to identify potential outliers and their specific effects on the regression equation. For each model, I excluded all cases that exceeded the convention cut-off point for Cook's D of $(4 / n)$, which is in our case 0.143 , and rerun the OLS regression. All of the reported effects above remained significant and did not change substantially even after removing influential data points, except for the effect in the last model indicating that parties in crisis-hit countries apply less criticism on the EU establishment. This effect dissolved after excluding Germany's right-wing party AfD (Cook's D $=0.1854$ ) from the model. For a summary of the regression diagnostics please consider the online Appendix. 
9. As France does not perfectly fit into the category of a crisis-hit country, I run additional OLS regressions where France is considered as an ambiguous case and is treated as the reference category for the two dummy variables crisis-hit vs. crisis-spared instead. However, the results for $\mathrm{H} 5 \mathrm{a}$ and $\mathrm{H} 5 \mathrm{~b}$ did not change substantially. The additional calculations are provided in the online Appendix.

10. A closer look at specific press releases revealed, that the Austrian FPÖ predominantly attacked immigrants and minorities, while the BZÖ primarily railed against crisis-hit EU member countries, EU candidate countries, or Third Countries in general, without explicitly attacking any immigrants or minorities. In France, all the exclusive statements were originating from the Front National, and they mainly zeroed in on asylum seekers or immigrants from specific Third Countries. Greek parties in turn directed their criticism at immigrants and minorities in general. However, no specific pattern was apparent regarding the exclusionary statements of German parties, as they were all directed at different target groups.

\section{Appendix}

Table 2. Descriptive statistics: Scales for used elements and direction of populism

\begin{tabular}{lccccc}
\hline Scale & Obs & Mean & Std.Dev. & Min & Max \\
\hline popcom & 28 & 38.95 & 22.51 & 5.66 & 87.06 \\
anti-elitist & 28 & 36.68 & 22.19 & 1.89 & 85.88 \\
exclusive & 28 & 2.27 & 3.47 & 0 & 10.75 \\
NATpop & 28 & 22.92 & 19.57 & 0 & 64.71 \\
EUpop & 28 & 5.83 & 5.3 & 0 & 18.18 \\
NATantiesta & 28 & 47.41 & 20.68 & 9.09 & 100 \\
EUantiestab & 28 & 21.89 & 18.46 & 0 & 66.67 \\
& & & & & \\
\hline
\end{tabular}

\section{List of table and figures in the online Appendix}

S1: Alternative operationalisation for a party's ideological position and government status.

S2: Country-specific macroeconomic data.

S3: Political position and number of press releases for Austrian, German, French \& Greek parties.

S4: OLS regressions after identification of influential data points (Cook's D $>4 / n$ ).

S5: Alternative OLS regressions when France is not considered a crisis-hit country. 


\section{References}

Aalberg, T., Esser, F., Reinemann, C., Strömbäck, J. and de Vreese, C. H. (eds.) (2017) Populist Political Communication in Europe. New York: Routledge.

Albertazzi, D. and McDonnell, D. (eds.) (2008) Twenty-First Century Populism: The spectre of Western European Democracy. Houndmills / Basingstoke / Hampshire: Palgrave Macmillan.

Aslanidis, P. (2015) 'Is Populism an Ideology? A Refutation and a New Perspective', Political Studies. Epub ahead of print 5 October 2015. DOI: 10.1111/1467-9248.12224.

Bakker, R., Edwards, E. E., Hooghe, L., Jolly, S., Marks, G., Polk, J., Rovny, J., et al. (2015) '2014 Chapel Hill Expert Survey. Version 2015.1 ', Chapel Hill, NC: University of North Carolina, Chapel Hill. Available at: www.chesdata.eu (accessed 28 December 2015)

Barr, R. R. (2009) 'Populists, Outsiders and Anti-Establishment Politics', Party Politics, 15(1), 29-48.

Barroso, J. M. D. (2013) Speech 13/346 at the Brussels Think Tank Dialogue on 22. April 2013. Brussels: European Commission. Available at: http://europa.eu/rapid/press-release_SPEECH-13346_en.htm (accessed 20 September 2014).

Bartolini, S. (2005) Restructuring Europe: centre formation, system building and political structuring between the nation-state and the European Union. Oxford / New York: Oxford University Press.

Betz, H.-G. (2015) 'The Revenge of the Ploucs: The Revival of Radical Populism under Marine Le Pen in France', in H. Kriesi and T. S. Pappas (eds.), European Populism in the Shadow of the Great Recession. ECPR Press, pp. 75-90.

Börzel, T. A. and Risse, T. (2000) 'Who is afraid of a European federation? How to constitutionalise a multi-level governance system', in C. Joerges, Y. Mény and J. H. H. Weiler (eds.), What kind of constitution for what kind of polity? Responses to Joschka Fischer. Florence, Italy: European University Institute, pp. 45-59.

Brubaker, R. (2011) 'Economic Crisis, Nationalism, and Politicized Ethnicity', in C. Calhoun and G. Derluguian (eds.), The Deepening Crisis. Governance Challenges After Neoliberalism. New York / London: New York University Press, pp. 93-108.

Bruter, M. (2005) Citizens of Europe? The Emergence of a mass European identity. Houndmills / Basingstoke / Hampshire: Palgrave Macmillan.

Canovan, M. (1999) 'Trust the People! Populism and the Two Faces of Democracy', Political Studies, XLVII, 2-16. 
Dechezelles, S. and Neumayer, L. (2010) 'Introduction: Is Populism a Side-Effect of European Integration? Radical Parties and the Europeanization of Political Competition', Perspectives on European Politics and Society, 11(3), 229-36.

Döring, H. and Manow, P. (2015) 'Parliaments and governments database (ParlGov): Information on parties, elections and cabinets in modern democracies'. Available at: www.parlgov.org (accessed 16 March 2016).

European Commission (2014) 'Macroeconomic Imbalances, France 2014', Occasional Papers 178, March. Available at:

http://ec.europa.eu/economy_finance/publications/occasional_paper/2014/pdf/ocp 178_en.pdf (accessed 16 December 2016).

Halikiopoulou, D., Nanou, K. and Vasilopoulou, S. (2012) 'The paradox of nationalism: The common denominator of radical right and radical left euroscepticism', European Journal of Political Research, 51(4), 504-39.

Hartleb, F. (2012) 'European Project in Danger? Understanding Precisely the Phenomena "Euroscepticsm, Populism and Extremism" in Times of Crisis', Review of European Studies, 4(5), 45-63.

Hartleb, F. (2013) 'Rechtspopulisten als Krisengewinnler in West- und Osteuropa?', Gesellschaft Wirtschaft Politik, 62(1), 69-80.

Heine, S. (2010) 'Left versus Europe? The Ideologies Underlying the Left's 'No' to the Constitutional Treaty in France and Germany', Perspectives on European Politics and Society, 11(3), 313-32.

Herrmann, R. K. and Brewer, M. B. (2004) 'Identities and Institutions: Becoming European in the EU', in R. K. Herrmann, T. Risse and M. B. Brewer (eds.), Transnational Identities. Becoming European in the EU. Lanham, MD: Rowman \& Littlefield, pp. 1-24.

Hooghe, L., Marks, G. and Wilson, C. J. (2002) 'Does Left/Right Structure Party Positions on European Integration?', Comparative Political Studies, 35(8), 965-89.

International Monetary Fund (2014) '2014 Artivle IV Consultation — Staff Report; Press Release; and Statement by the Executive Director for France', IMF Country Report No. 14/182. Avaliable at: www.imf.org/external/pubs/ft/scr/2014/cr14182.pdf (accessed 18 December 2016).

Jagers, J. and Walgrave, S. (2007) 'Populism as political communication style: An empirical study of political parties' discourse in Belgium', European Journal of Political Research, 46(3), 319-45.

Kitschelt, H. and McGann, A. J. (1995) The Radical Right in Western Europe. A Comparative Analysis. Ann Arbor: University of Michigan Press. 
Kriesi, H. and Pappas, T. S. (2015a) 'Populism in Europe During Crisis: An Introduction', in H. Kriesi and T. S. Pappas (eds.), European Populism in the Shadow of the Great Recession. ECPR Press, pp. 1-19.

Kriesi, H. and Pappas, T. S. (eds.) (2015b) European Populism in the Shadow of the Great Recession. ECPR Press.

Kriesi, H., Grande, E., Lachat, R., Dolezal, M., et al. (2006) 'Globalization and the transformation of the national political space: Six European countries compared', European Journal of Political Research, 45(6), 921-56.

Lutz, W., Kritzinger, S. and Skirbekk, V. (2006) 'POPULATION: The Demography of Growing European Identity', Science, 314(5798), 425-5.

McLaren, L. M. (2007) 'Explaining Mass-Level Euroscepticism: Identity, Interests, and Institutional Distrust', Acta Politica, 42(2), 233-51.

Mudde, C. (2004) 'The Populist Zeitgeist', Government and Opposition, 39(4), 541-63.

Pappas, T. S. (2014) Populism and Crisis Politics in Greece. Houndmills, Basingstoke, Hampshire; New York NY: Palgrave Macmillan.

Pauwels, T. (2011) 'Measuring Populism: A Quantitative Text Analysis of Party Literature in Belgium', Journal of Elections, Public Opinion \& Parties, 21(1), 97-119.

Priester, K. (2012) 'Wesensmerkmale des Populismus', Aus Politik und Zeitgeschichte, 62(5-6), 3-8.

Reungoat, E. (2010) 'Anti-EU Parties and the People: An Analysis of Populism in French Euromanifestos', Perspectives on European Politics and Society, 11(3), 292-312.

Roodujin, M. and Akkerman, T. (2015) 'Flank attacks: Populism and left-right radicalism in Western Europe', Party Politics. Epub ahead of print 23 June 2015. DOI: 10.1177/1354068815596514.

Rooduijn, M. and Pauwels, T. (2011) 'Measuring Populism: Comparing Two Methods of Content Analysis', West European Politics, 34(6), 1272-83.

Rooduijn, M., de Lange, S. L. and van der Brug, W. (2012) 'A populist Zeitgeist? Programmatic contagion by populist parties in Western Europe', Party Politics, 20(4), 563-75.

Scharpf, F. W. (1999) Governing in Europe: effective and democratic? Oxford / New York: Oxford University Press. 
Taggart, P. A. (1998) 'A touchstone of dissent: Euroscepticism in contemporary Western European party systems', European Journal of Political Research, 33(3), 363-88.

Taggart, P. A. (2000) Populism. Buckingham / Philadelphia: Open University Press.

Vasilopoulou, S., Halikiopoulou, D. and Exadaktylos, T. (2014) 'Greece in Crisis: Austerity, Populism and the Politics of Blame', Journal of Common Market Studies, 52(2), 388-402. 